\begin{tabular}{|c|c|c|}
\hline & International Journal of Current Research in & \\
\hline & Biosciences and Plant Biology & \\
\hline PUBLI & $\begin{array}{c}\text { ISSN: 2349-8080 (Online) } \bullet \text { Volume } \mathbf{3} \bullet \text { Number } 5 \\
\text { Journal homepage: } \underline{\mathbf{w} w \text { w.ijcrbp.com }}\end{array}$ & \\
\hline
\end{tabular}

\title{
Characterization of Sugarcane (Saccharum officinarum L.) Cultivars of Republic of Benin
}

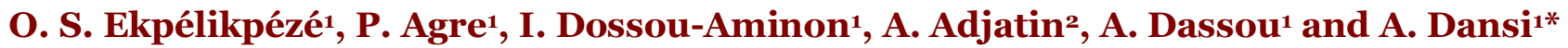 \\ ${ }^{1}$ Laboratory of Biotechnology, Genetic Resources and Plant and Animal Breeding (BIORAVE), Faculty of Sciences and \\ Technology of Dassa, Polytechnic University of Abomey (UPA), BP14, Dassa, Benin \\ ${ }_{2}^{2}$ Faculty of Sciences and Technology of Dassa, Polytechnic University of Abomey (UPA), BP14, Dassa, Benin
}

*Corresponding author.

\begin{tabular}{|c|c|}
\hline Abstract & Article Info \\
\hline \multirow{11}{*}{$\begin{array}{l}\text { In Benin, sugarcane (Saccharum officinarum L.), is both a food security and cash crop } \\
\text { neglected by scientific research and development programs. To assess its diversity at } \\
\text { national level, } 89 \text { farmer-named cultivars were collected from different production } \\
\text { zones, planted in completely randomized bloc design with three repetitions and } \\
\text { characterized using } 15 \text { qualitative and } 10 \text { quantitative morphological parameters. Data } \\
\text { collected were analyzed using descriptive statistics and multivariate analysis. Among } \\
\text { the qualitative traits, five (color of the stipule, leaflet cover, pubescence of the leaves, } \\
\text { external color and split of the stem) presented high variability. Among the stem colors } \\
\text { recorded, black ( } 49.44 \%) \text {, red }(14.49 \%) \text { and yellow }(13.48 \%) \text { were the most } \\
\text { represented. Apart the leaves length, all of the quantitative traits considered exhibited } \\
\text { high variability hence indicating the possibility of improvement of the crop using local } \\
\text { germplasm to respond to farmers and consumers' preferences and needs. Correlation } \\
\text { matrix revealed strong relationships between different quantitative traits. Both principal } \\
\text { component analysis (PCA) and cluster analysis grouped the } 89 \text { cultivars into four } \\
\text { morphological groups with different characteristics. Some putative duplicates were } \\
\text { identified and for their certification the use of molecular markers such as SSRs or } \\
\text { advanced techniques such as GBS were recommended. }\end{array}$} & $\begin{array}{l}\text { Accepted: 05April } 2016 \\
\text { Available Online: } 06 \text { May } 2016\end{array}$ \\
\hline & Ke ywords \\
\hline & Agromorphological characterization \\
\hline & Cultivar \\
\hline & $\begin{array}{l}\text { Saccharum officinarum L. } \\
\text { Sugarcane }\end{array}$ \\
\hline & \\
\hline & \\
\hline & \\
\hline & \\
\hline & \\
\hline & \\
\hline
\end{tabular}

\section{Introduction}

Member of Poaceae family, the gender Saccharum contains six species among which two wild and poor in sugar (Saccharum spontaneum and Saccharum robustum) and four cultivated (Saccharum officinarum, Saccharum barberi, Saccharum sinense and Saccharum edule) rich in sugar (Nair, 2009). Native to Southeast Asia, sugarcane (Saccharum officinarum L.) is a food crop that plays an essential economic role in many tropical and subtropical countries (Jangpromma et al., 2010; Singh et al., 2010). It is very rich in carbohydrates, minerals, fiber and vitamin B6 (Archimede et al., 2011).
Sugarcane cultivation enriches soil in organic matter and allows better conservation of their structure (Bell et al., 2001). Although sugar and rum markets have always been the prerogative of this crop, other markets such as energy and biofuels are also opening (Small and Catling, 2006).

In Benin, Saccharum officinarum is grown in lowlands of different agro-ecological regions and is an important source of household income for rural producers (Ekpélikpézé et al., 2016a). Its production is mostly used by $\mathrm{SuCoBe}$, a Chinese sugar industry installed at Savè, district of central Benin, for ethanol production 
(Ekpélikpézé et al., 2016a). However, despite its economic importance, sugarcane still remains scientifically under-researched in Benin. Its production is facing many biotic and abiotic constraints causing huge losses to producers (Ekpélikpézé et al., 2016a). Recently, an ethnobotanical study was conducted in the production zones and helped to understand the on farm management of the existing diversity and identify production constraints and farmers' preference criteria (Ekpelikpezé et al., 2015). Physicochemical analysis was also carried out to support decision making with regard to the use of the cultivars (Ekpélikpézé et al., 2016b).

The development of an economically profitable production of any plant species like sugarcane undoubtedly requires the use of improved high yielding varieties. To facilitate breeding efforts, characterisation of available germplasm is a necessary first step since it especially benefits a plant breeder in choosing proper parental materials (Pandey et al., 2011). Also knowledge about interrelationships among descriptors (characteristics), from a plant breeder's perspective, aids in the selection of superior genotypes from the breeding population and is important in planning and evaluating breeding programmes (Sheela and Gopalan, 2006).

The objectives of this study were to assess the diversity among local sugarcane cultivars in Benin using agromorphological descriptors and to study interrelationships among descriptors used in order to identify outstanding accessions that could be involved in national breeding programs for the benefit of both producers and consumers.

\section{Materials and methods}

\section{Plant material and cultivation}

The plant material is composed of eighty-nine (89) sugarcane accessions collected in different production areas in Benin (Table 1) and maintained as a field collection at the experimental site of the Faculty of Science and Technology (FAST) of Dassa located at Djrègbé, a village of south-eastern Benin. Djrègbé is a humid zone characterized by four seasons (two rainy and two dry) with an average rainfall exceeding 1100 $\mathrm{mm} /$ year.

Soils are in majority hydromorphic, the average temperature is about $27^{\circ} \mathrm{C}$ and the relative humidity is relatively high (Akoègninou et al., 2006). For each accession, cuttings of $30 \mathrm{~cm}$ length were planted on straight row and on a Completely Randomized Block Design with three repetitions. Distance between ridges and between plants was kept at $1 \mathrm{~m}$ and $1.55 \mathrm{~m}$ respectively following Abdelmahmud et al. (2012).

Table 1: List of sugarcane (Saccharum officinarum) accessions studied and their origin.

\begin{tabular}{|c|c|c|c|c|c|}
\hline $\mathbf{N}^{\mathbf{0}}$ & Accession no. & Vernacular names & Collection sites & Districts & Departments \\
\hline 1 & AT13 & Gartin fonharoun & Bocossi & Péhunco & Atacora \\
\hline 2 & AT14 & Gartin wonka & Bocossi & Péhunco & Atacora \\
\hline 3 & AT15 & Gartin Dombourou & Bocossi & Péhunco & Atacora \\
\hline 4 & AT16 & Archibi & Kparatéki & Kérou & Atacora \\
\hline 5 & AT17 & Alékébogoun & Gounsaroun & Kérou & Atacora \\
\hline 6 & Atl67 & Azéléké & Kpé Aholouko & Calavi & Atlantique \\
\hline 7 & Atl68 & Azéléké & Assogbénoukpèvi & Kpomassè & Atlantique \\
\hline 8 & Atl69 & Azéléké & Assogbénoudaho & Kpomassè & Atlantique \\
\hline 9 & Bo18 & Alékédoudou & Titirou & Parakou & Borgou \\
\hline 10 & Bo19 & Alékéolomihessou & Titirou & Parakou & Borgou \\
\hline 11 & Bo20 & Alékéolomiwé & Titirou & Parakou & Borgou \\
\hline 12 & Bo21 & Alékéolomiwé & Titirou & Parakou & Borgou \\
\hline 13 & $\mathrm{Co} 25$ & Arékébaki & Agbo & Savè & Collines \\
\hline 14 & $\mathrm{Co} 26$ & Arékéfari & Agbo & Savè & Collines \\
\hline 15 & $\mathrm{Co} 27$ & Aréké Tourawa & Agbo & Savè & Collines \\
\hline 16 & $\mathrm{Co} 28$ & Léké founfoun & Alafia & Savè & Collines \\
\hline 17 & Co29 & Léké kpikpa & Alafia & Savè & Collines \\
\hline 18 & Co30 & Léké doudou & Alafia & Savè & Collines \\
\hline 19 & Do01 & Kantooma & Doguê & Bassila & Donga \\
\hline 20 & Do02 & Karakoukpéto & Timba & Djougou & Donga \\
\hline 21 & Do03 & Karakouhouloumou & Timba & Djougou & Donga \\
\hline 22 & Do04 & Karaisoori & Toko-Toko & Djougou & Donga \\
\hline 23 & Do05 & Karaipieri & Toko-Toko & Djougou & Donga \\
\hline
\end{tabular}




\begin{tabular}{|c|c|c|c|c|c|}
\hline $\mathbf{N}^{0 .}$ & Accession no. & Vernacular names & Collection sites & Districts & Departments \\
\hline 24 & Do06 & Ipèokanga ignonyé & Affongosso & Djougou & Donga \\
\hline 25 & Do07 & Ipèokanga ipègni & Affongosso & Djougou & Donga \\
\hline 26 & Do08 & Ipèokanga ipègni & Affongosso & Djougou & Donga \\
\hline 27 & Do09 & Karai Itchirè & Copargo centre & Copargo & Donga \\
\hline 28 & Do10 & Karai Kparè & Copargo centre & Copargo & Donga \\
\hline 29 & Do11 & Gnankaniguê & Pabegou & Copargo & Donga \\
\hline 30 & Do12 & Gnankani Mori & Pabegou & Copargo & Donga \\
\hline 31 & Do22 & Gnakani Mori & Pabegou & Copargo & Borgou \\
\hline 32 & Do23 & Gnankaniguê & Pabegou & Copargo & Borgou \\
\hline 33 & Do24 & Karaikoukpéti & Déguina & Bassila & Borgou \\
\hline 34 & Mo31 & Souclétchi Mamoui & Sèwokondji & Mono & Mono \\
\hline 35 & Mo32 & Léké Mamoui & Djanglanmè & Grand popo & Mono \\
\hline 36 & Mo33 & Léké wéwé & Djrado & Porto-Novo & Mono \\
\hline 37 & Mo34 & Souclétin Hé & Sèwokondji & Grand popo & Mono \\
\hline 38 & Mo35 & Souclétin Hi & Sèwokondji & Grand popo & Mono \\
\hline 39 & Mo36 & Léké vêê & Djanglanmè & Grand popo & Mono \\
\hline 40 & Mo37 & wandanwandan & Donkondji & Athiémé & Mono \\
\hline 41 & Mo38 & Azélékéyibo & Donkondji & Athiémé & Mono \\
\hline 42 & Мo39 & Founfounyibo & Aguinhoué & Grand popo & Mono \\
\hline 43 & Mo40 & Souclétin Djin & Sèwokondji & Grand popo & Mono \\
\hline 44 & Mo41 & Founfoun Djin & Aguinhoué & Grand popo & Mono \\
\hline 45 & Mo42 & Founfoun Djin & Aguinhoué & Grand popo & Mono \\
\hline 46 & Mo43 & Konakri & Aguinhoué & Grand popo & Mono \\
\hline 47 & Mo78 & Founfoun You & Sazoué & Athiémé & Mono \\
\hline 48 & Mo79 & Azélékédaho & Agonvè & Lokossa & Mono \\
\hline 49 & Mo80 & Azéléké Huinihuini & Agonvè & Lokossa & Mono \\
\hline 50 & Mo81 & Lékéwéwé & Agonvè & Lokossa & Mono \\
\hline 51 & Mo82 & Léké vovo & Agonvè & Lokossa & Mono \\
\hline 52 & Mo83 & Dawéléké & Tanvè & Bopa & Mono \\
\hline 53 & Mo84 & Azéléké & Tanvè & Вора & Mono \\
\hline 54 & Mo85 & Léké vovo & Tanvè & Bopa & Mono \\
\hline 55 & Oue44 & Azéléké & Dangbo & Ouémé & Ouémé \\
\hline 56 & Oue45 & Lékékoklodjonon & Dangbo & Ouémé & Ouémé \\
\hline 57 & Oue46 & Azéléké & Tovè & Dangbo & Ouémé \\
\hline 58 & Oue47 & Azéléké vêvê & Tovè & Dangbo & Ouémé \\
\hline 59 & Oue48 & Azéléké gokpitikpiti & Tovè & Dangbo & Ouémé \\
\hline 60 & Oue49 & Azéléké & Abato & Adjohoun & Ouémé \\
\hline 61 & Oue50 & Atinwlinwlin & Abato & Adjohoun & Ouémé \\
\hline 62 & Oue51 & Léké fèfè & Djèrègbé & Sèmè-Kpodji & Ouémé \\
\hline 63 & Oue52 & Gounléké & Afamè & Adjohoun & Ouémé \\
\hline 64 & Oue59 & Azéléké & Kpodji & Sèmè-Kpodji & Ouémé \\
\hline 65 & Oue60 & Azéléké & Kpodji & Sèmè-Kpodji & Ouémé \\
\hline 66 & Oue61 & Azéléké & Djèrègbé & Sémè-Kpodji & Ouémé \\
\hline 67 & Oue62 & Azéléké Assi & Agonsagbo & Sèmè-Kpodji & Ouémé \\
\hline 68 & Oue63 & Azéléké Assou & Agonsagbo & Sèmè-Kpodji & Ouémé \\
\hline 69 & Oue64 & Azéléké Wiwi & Djeffa & Sèmè-Kpodji & Ouémé \\
\hline 70 & Oue65 & Azéléké Vôvô & Djeffa & Sèmè-Kpodji & Ouémé \\
\hline 71 & Oue66 & Azéléké & Agongo & Sèmè-Kpodji & Ouémé \\
\hline 72 & Oue76 & Azéléké & Agbokou & Porto-Novo & Ouémé \\
\hline 73 & Oue77 & Lékéwéwé & Agbokou & Porto-Novo & Ouémé \\
\hline 74 & Pla53 & Iréké Oniandoudou & Monsafè & Kétou & Plateau \\
\hline 75 & Pla54 & Yéké foufou & OKéodon & Adjawèrè & Plateau \\
\hline 76 & Pla55 & Yéké fonton & Goézi & Adjawèrè & Plateau \\
\hline 77 & Pla56 & Yéké & Goézi & Adjawèrè & Plateau \\
\hline 78 & Pla57 & Ogniguin & Onigbolo & Pobè & Plateau \\
\hline 79 & Pla58 & Iréké doudou & Pobè & Pobè & Plateau \\
\hline
\end{tabular}




\begin{tabular}{|c|c|c|c|c|c|}
\hline $\mathbf{N}^{\mathbf{0}}$ & Accession no. & Vernacular names & Collection sites & Districts & Departments \\
\hline 80 & Pla86 & Aléké Kpikpa & Gbodogui & Pobè & Mono \\
\hline 81 & Pla87 & Alékédoudou & Igbo Idi & Pobè & Mono \\
\hline 82 & Pla88 & Léké Akparon & Igbo Idi & Pobè & Mono \\
\hline 83 & Pla89 & Aléké Kpikpa & Igbo Idi & Pobè & Mono \\
\hline 84 & Zo70 & Sèmèléké & Toué & Covè & Zou \\
\hline 85 & Zo71 & Sèmèlékéwiwi & Bamè & Zangnannado & Zou \\
\hline 86 & Zo72 & Sèmèléké vovo & Bamè & Zangnanado & Zou \\
\hline 87 & Zo73 & Gbaglo & Bamè & Zangnanado & Zou \\
\hline 88 & Zo74 & Léké vovo & Zouto & Djidja & Zou \\
\hline 89 & Zo75 & Léké wéwé & Zouto & Djidja & Zou \\
\hline
\end{tabular}

\section{Data collection and analysis}

Twenty six parameters (15 qualitative and 11 quantitative) selected among sugarcane descriptors (IPGRI, 1994) were used. List, measurement methods and levels of score of the parameters are summarised on Tables 2 and 3. Following Abdelmahmoud et al. (2012), all the data were collected at 180 days after planting except the number of suckers taken 60 days after planting.

Table 2: Qualitative traits used for morphological evaluation and their scoring levels.

\begin{tabular}{|c|c|c|c|}
\hline Qualitative data & Type of variable & Code & Evaluation level \\
\hline \multirow[t]{11}{*}{$\begin{array}{l}\text { Data taken at } 6 \text { months } \\
\text { after planting }\end{array}$} & Stem external color & SEC & $\begin{array}{l}\text { Yellow (1), Green (2), Black (3), Red (4), Yellow } \\
\text { reddish (5), Brown green (6), Violet (7) }\end{array}$ \\
\hline & Internal color of the stem & ICS & White (1), Other (2) \\
\hline & Limb color & $\mathrm{LC}$ & Green (1) Other (2) \\
\hline & Stipule color & $\mathrm{SC}$ & Green(1), Yellow (2), Red (3), Brown (4), Other (5) \\
\hline & Color of the leaflet & $\mathrm{CL}$ & Brown (1), Brown green (2), Green (3), Other (4) \\
\hline & Pubescence of leaflet & PL & Present (1), absent (0) \\
\hline & Shape of the buds & SB & Oval (1), other (2) \\
\hline & Bud cover & $\mathrm{BC}$ & Present (1), absent (0) \\
\hline & Prunescence & Pru & Present (1), absent (0) \\
\hline & Leaflet cover & $\mathrm{LC}$ & Close (1), other (2) \\
\hline & Alignment of internode & AIn & Heterogeneous (1), other (2) \\
\hline \multirow{4}{*}{$\begin{array}{l}\text { Data taken at } 12 \text { months } \\
\text { after planting }\end{array}$} & Flowering & Flo & Present (1), absent (0) \\
\hline & Split of the stem & $\mathrm{SpS}$ & Present (1), Absent (0) \\
\hline & Shape of inter-node & SIN & Cylindrical (1), Other (2) \\
\hline & Node swelling & NS & Non swelling (1), Other (2) \\
\hline
\end{tabular}

Table 3: Quantitative data used for morphological evaluation and their measurement.

\begin{tabular}{|c|c|c|}
\hline Data collecting period & Quantitative traits & Measurement techniques \\
\hline Two months after planting & Sucker number & Count of the number of suckers \\
\hline \multirow[t]{8}{*}{ Six months after planting } & Leaf width $(\mathrm{cm})$ & $\begin{array}{l}\text { Width of the broadest portion of the third fully opened } \\
\text { leaf from tip measured }\end{array}$ \\
\hline & Length of the leaf $(\mathrm{cm})$ & $\begin{array}{l}\text { Distance between the leaf tip and base measured on the } \\
\text { third fully opened leaf from the tip. }\end{array}$ \\
\hline & Length of stipule (cm) & Measured in $\mathrm{cm}$ \\
\hline & Stem diameter $(\mathrm{cm})$ & $\begin{array}{l}\text { Recorded after cutting the stem and on three different } \\
\text { plants }\end{array}$ \\
\hline & Internode length $(\mathrm{cm})$ & $\begin{array}{l}\text { Distance between two consecutive nodes measured on } \\
\text { the stem }\end{array}$ \\
\hline & Bud size $(\mathrm{cm})$ & Distance between the base of the bud and its tip \\
\hline & Number of internodes & Count of the number of internodes on $1 \mathrm{~m}$ \\
\hline & Node diameter $(\mathrm{cm})$ & An horizontal measure of stem cut at the node level \\
\hline \multirow[t]{2}{*}{12 months after planting } & Stem weight $(\mathrm{kg})$ & Leaves removed and the sucker weighted \\
\hline & Plant size (m) & Measured from ground to the top of the plant \\
\hline
\end{tabular}




\section{Results and discussion}

\section{Variability of qualitative traits}

The distribution of the accessions following the modalities of the qualitative variables is presented on Fig. 1. Low variability was observed for the leaf pubescence (LP) and the split of the stem (SpS) characters while high variability was recorded for the external color of the stem (ECS), the stipule color (SC) and the color of the leaf sheath (CLS). The majority $(85.39 \%)$ of the collected accessions were pubescent and most (76.4\%) of them do not exhibit inter-nodes cracking. On sugarcane markets, stems with inter-nodes cracking are disliked by the consumers. In the fields, cultivars whose stems generally exhibit inter-nodes cracking are not preferred by the producers as they get rot faster than uncracked stems (Ekpélikpézé et al., 2016a). Within the collection studied, accessions with black stem (49.44\%), red wine stem (14.49\%) and yellow stem $(13.48 \%)$ are the most represented and account, altogether, for $67.041 \%$ of the accessions (Fig. 1). Concerning the color of the stipule, three types (brown, dark green, green) were observed in the proportions of $66.29 \%, 17.98 \%$ and $15.73 \%$ respectively. The color of the leaf was also variable. Brown color was the most recorded $(53.93 \%)$ followed by than green $(16.86 \%)$, yellow (15.73\%) and red (13.48\%) color. Within the parameters considered, no geographical distribution of the modalities is observed as the general tendency of predominance in the study area was also the same for each of the regions surveyed (Table 2).

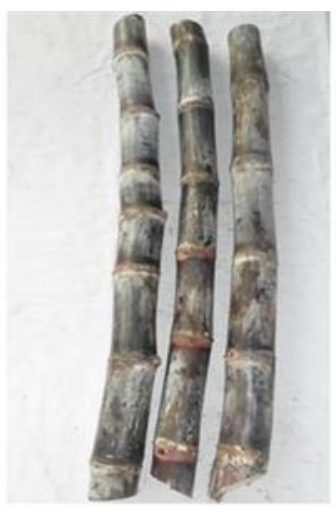

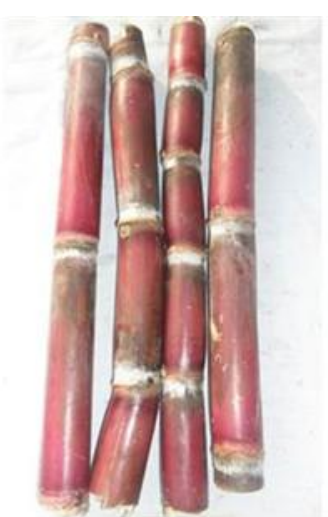

Wine red stem

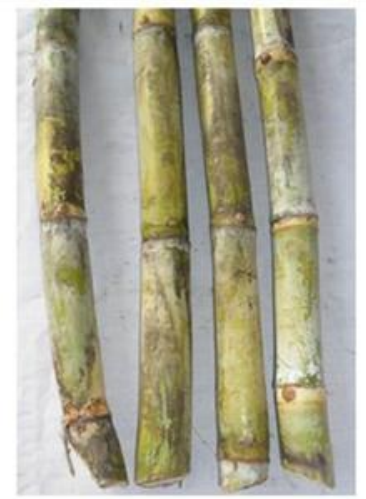

Green stem

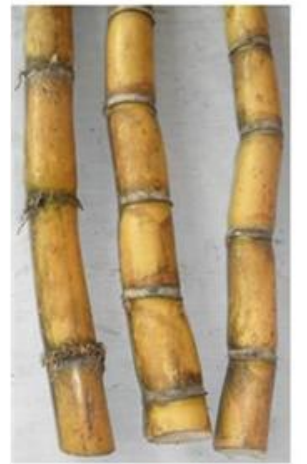

Yellow stem

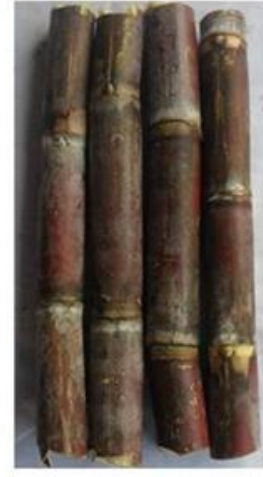

Red stem

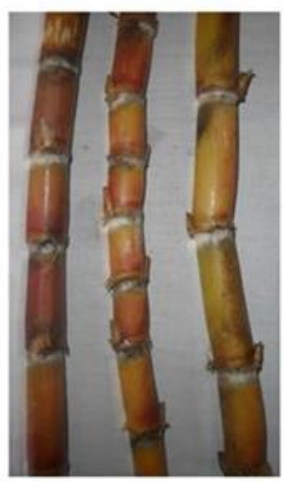

Reddish stem Dark green stem

Fig. 1: Variability of the stem external color of the sugarcane cultivars collected in Benin.

Out of the 15 qualitative traits considered, Principal Component Analysis helped to identify five (color of the stipule, leaflet cover, pubescence of the leaves, external color and split of the stem) that are highly discriminative and useful for sugarcane germplasm characterization. Using these five qualitative parameters and the UPGMA clustering method, the accessions were classified into three classes named $\mathrm{C} 1, \mathrm{C} 2$ and $\mathrm{C} 3$ (Fig. 2). C1 groups most of the accessions having black stem, C2 mostly gathers accessions of yellow stem while accessions with green stem dominate C3. The dendrogram constructed (Fig. 2) showed the existence of an important phenotypic diversity with the presence of some accessions with different phenotypic traits in the same cluster and also 
the presence of many probable duplicates. This calls for the use of molecular markers such as SSR or SNP to assess the genetic diversity, clarify synonymies and identify duplicates with the germplasm following Grivet and Arruda (2001), Silva et al. (2005), Edmé et al. (2005), Kawar et al. (2009), Pinto et al. (2011) and Gouy (2012). Qualitative traits have been used to assess genetic diversity in many other crops such as cassava (Agre et al., 2015), sorghum (Dossou-Aminon et al., 2015), millet (Sy et al., 2015) and spider plant (Kiebre et al., 2015).

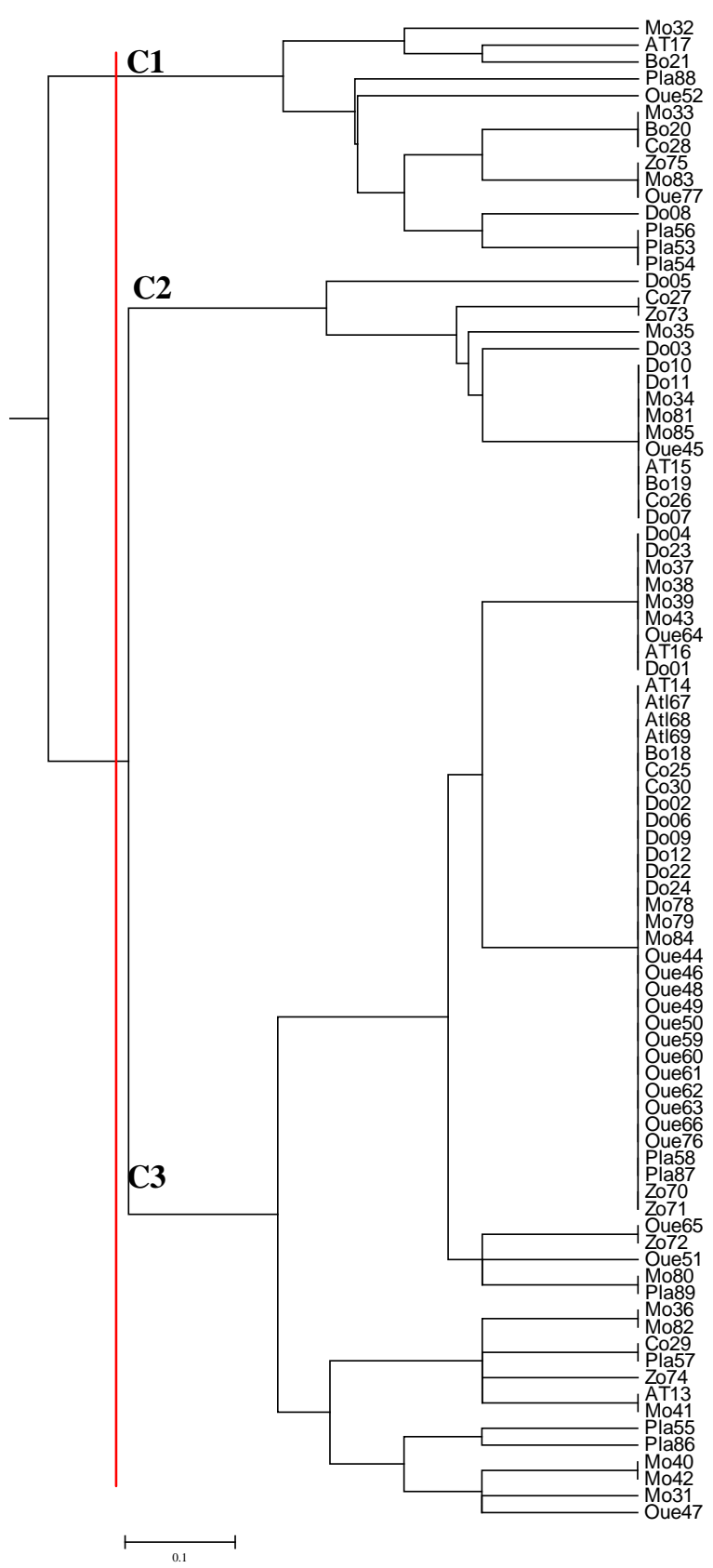

Fig. 2: Dendrogram of 89 sugarcane cultivars using UPGMA clustering method.

\section{Variability of quantitative traits}

Quantitative data of Saccharum officinarum analyzed through descriptive statistical (minimum, maximum, average mean, Standard deviation, coefficient of variation) were presented in Table 4. High variation were observed between the minimum and the maximum for some traits such as stem weight (SW), bud size (BS), internodes length (IL), stem diameter (SD), leaf width (LW) and the plant size (PS). The stem weight per meter varies from $1.63 \mathrm{~kg}$ to $6.80 \mathrm{~kg}$ with an average of 4.21 $\mathrm{kg}$. The bud size it varies from $0.46 \mathrm{~cm}$ to $1.17 \mathrm{~cm}$ with $0.81 \mathrm{~cm}$ as average. The internodes length and stem diameter varied respectively from $6.13 \mathrm{~cm}$ to $18.86 \mathrm{~cm}$ and $1.82 \mathrm{~cm}$ to $6.06 \mathrm{~cm}$. Concerning the size of the sugarcane at harvest time, the average mean was estimated to $5.4 \mathrm{~m}$ and the smallest value was $3.92 \mathrm{~m}$ while the highest was $6.61 \mathrm{~m}$. The leaf width that inform on total biomass varies from $4.81 \mathrm{~cm}$ to $9.09 \mathrm{~cm}$ with $7.28 \mathrm{~cm}$ on average. Across the literature, quantitative genetic studies on sugarcane related to the yield were principally based on biomass, plant size, stem weight, stem diameter and the number of sucker (Silva et al., 2005; Gouy, 2012).

In general, the majority of the quantitative traits used presented high coefficients of variations $(\mathrm{CV})$. These CVs vary from $6.58 \%$ (leaf length) to $26.35 \%$ (stem weight). The high value (CV>20\%) of these parameters were observed with stem weight per meter $(26.35 \%)$ and the bud size $(22.38 \%)$. These results show the importance of quantitative traits in assessing sugarcane diversity in Benin. These results are similar to those reported by Dossou-Aminon et al. (2015) on sorghum (Sorghum bicolor) and Agre et al. (2015) on cassava (Manihot esculenta Crantz).

Significant correlations $(p<0.05)$ were observed between the quantitative variables. The highest positive correlation $(r=0.90)$ was obtained between the nodes' diameter (ND) and stem weight (SW) while the highest negative correlation $(r=-0.89)$ was between the nodes number and the internodes length. Moreover, the stem weight and stem diameter were highly correlated between themselves and with leaf width, leaf length and stipule length (Table 5). The correlation matrix showed that the plant height, bud height and the sucker number were not correlated with the others variables. These results indicated that the larger and heaviest the stem, the high its number of nodes and the small the distance between nodes. Muhammad and Farooq (2009) reported negative correlation between sucker number and the 
others yield variables. This difference could be explained by the counting time of the sucker which was done two months after sugarcane planting (Abdelmahmoud et al., 2012). The high coefficients of variation observed for most $(75 \%)$ of the studied traits indicated the presence of a high heterogeneity within the population characterized that can be exploited for breeding purpose in Benin. According to Agre et al. (2015), correlation data constitute an essential tool in the choice of characters to be integrated in a breeding scheme. The results of our study constitute an important database for sugarcane selection and varietal improvement programs in Benin.

Table 4: Descriptive statistics of quantitative traits.

\begin{tabular}{llllll}
\hline Parameters & Minimum & Maximum & Mean & Standard deviation & CV $(\%)$ \\
\hline LW & 4.81 & 9.09 & 7.276 & 1.339 & 18.40 \\
LL & 1.406 & 1.741 & 1.612 & 0.106 & 6.58 \\
LOL & 3.88 & 7.133 & 5.802 & 0.984 & 16.96 \\
SD & 2.05 & 5.89 & 4.032 & 0.788 & 19.54 \\
IL & 9.046 & 18.093 & 12.067 & 2.379 & 19.71 \\
SW & 1.135 & 6.305 & 4.186 & 1.103 & 26.35 \\
TN & 2 & 4 & 3.196 & 0.463 & 14.49 \\
BS & 0.473 & 1.533 & 0.706 & 0.158 & 22.38 \\
IN & 5.52 & 12.26 & 8.853 & 1.358 & 15.34 \\
ID & 2.7 & 5.58 & 4.296 & 0.798 & 18.58 \\
PH & 3.92 & 6.61 & 5.397 & 0.649 & 12.03 \\
\hline
\end{tabular}

Table 5: Correlations between the quantitative traits of sugarcane cultivars in Benin.

\begin{tabular}{|c|c|c|c|c|c|c|c|c|c|c|c|}
\hline Parameters & $\mathbf{L W}$ & $\mathbf{L L}$ & LOL & SD & IL & SW & SN & BS & DIN & ID & PS \\
\hline LW & 1.00 & & & & & & & & & & \\
\hline $\mathbf{L L}$ & $0.80 *$ & 1.00 & & & & & & & & & \\
\hline LOL & $0.70^{*}$ & $0.84 *$ & 1.00 & & & & & & & & \\
\hline SD & $0.82 *$ & $0.74 *$ & $0.56^{*}$ & 1.00 & & & & & & & \\
\hline IL & $-0.65^{*}$ & -0.49 & $-0.53 *$ & $-0.54 *$ & 1.00 & & & & & & \\
\hline SW & $0.85^{*}$ & $0.80 *$ & $0.68^{*}$ & $0.88 *$ & -0.47 & 1.00 & & & & & \\
\hline SN & 0.09 & 0.00 & 0.08 & 0.04 & -0.06 & 0.04 & 1.00 & & & & \\
\hline BS & -0.02 & 0.17 & 0.29 & 0.08 & -0.13 & 0.13 & -0.06 & 1.00 & & & \\
\hline DIN & $0.65^{*}$ & $0.54 *$ & $0.57 *$ & $0.60 *$ & $-0.89 *$ & $0.52 *$ & 0.06 & 0.13 & 1.00 & & \\
\hline ID & $0.87^{*}$ & $0.82 *$ & $0.70 *$ & $0.87 *$ & $-0.54^{*}$ & $0.90 *$ & -0.02 & 0.15 & $0.58 *$ & 1.00 & \\
\hline PS & 0.20 & 0.23 & 0.29 & 0.25 & -0.09 & 0.34 & 0.23 & 0.28 & 0.13 & 0.30 & 1.00 \\
\hline
\end{tabular}

*: Significant correlation $(\mathrm{R}>0.50)$ at $p<0.05$.

The principal component analysis (PCA) grouped the variables into different components of which the first four explained $85.59 \%$ of the total variability (Table 6). The first two components are the most relevant and contributed alone for $66.26 \%$ of the total morphological variability. The first factor (PC1) contributes to $54.61 \%$. Variables negatively correlated to PC1 were leaf width (LW), leaf length (LL), stipule length (SL), stem diameter (SD), stem weight (SW), Internodes number (IN) and nodes diameter (ND). Internodes length (IL) is positively correlated to $\mathrm{PC} 1$.

In this study, PC1 is important because most of the variables related to the sugarcane performance and to the crop development are well represented. The second component (PC2) contributed to $11.64 \%$ of the total variance. Plant height $(\mathrm{H})$ is the only one parameter negatively correlated to it. PC3 and PC4, contributed
$9.99 \%$ and $9.34 \%$ to the total variance respectively and are positively correlated to sucker number ( $\mathrm{SN}$ ) and to bud size (BS). Fig. 3 shows the projection of the accessions analyzed on the plan defined by the two factors PC1 and PC2. Four groups (Fig. 3) were observed. Group1 and group 3 are more represented on factor 1 . Accessions of group 1 are positively correlated while accessions of the group 3 are negatively correlated on this first factor. Accession of the group 2 and group 4 are positively correlated to factor 2 (Fig. 3). The group 1 has the largest number of accessions (48 accessions) while group 2 and group C3 gather together 17 and 24 accessions respectively. Group 4 has the lowest number of accessions. Accessions from different agro-ecological zones were grouped in same cluster and have the same performances. Results of this study are similar to those obtained by Adebo et al. (2015) on Corchorus olitorius and Gbaguidi et al. (2015) on Vigna unguiculata. 
Table 6: Eigen vectors and values for the four principal component axes.

\begin{tabular}{lcccc}
\hline Parameters & PC 1 & PC 2 & PC 3 & PC 4 \\
\hline LW & -0.92 & 0.17 & 0.13 & -0.12 \\
LL & -0.89 & -0.01 & -0.11 & -0.18 \\
LOL & -0.82 & -0.16 & -0.10 & 0.05 \\
SD & -0.88 & 0.08 & 0.03 & -0.20 \\
IL & 0.72 & -0.24 & -0.08 & -0.58 \\
SW & -0.91 & -0.05 & -0.01 & -0.30 \\
TN & -0.07 & -0.38 & 0.84 & 0.15 \\
BS & -0.19 & -0.62 & -0.56 & 0.38 \\
NN & -0.76 & 0.22 & 0.07 & 0.53 \\
ND & -0.93 & 0.01 & -0.07 & -0.22 \\
PH & -0.33 & -0.76 & 0.14 & -0.09 \\
Eigen value & 6.00 & 1.28 & 1.09 & 1.02 \\
Value & 54.61 & 11.64 & 9.99 & 9.34 \\
Cumulative percentage $\%$ & 54.61 & 66.26 & 76.25 & 85.59 \\
\hline
\end{tabular}

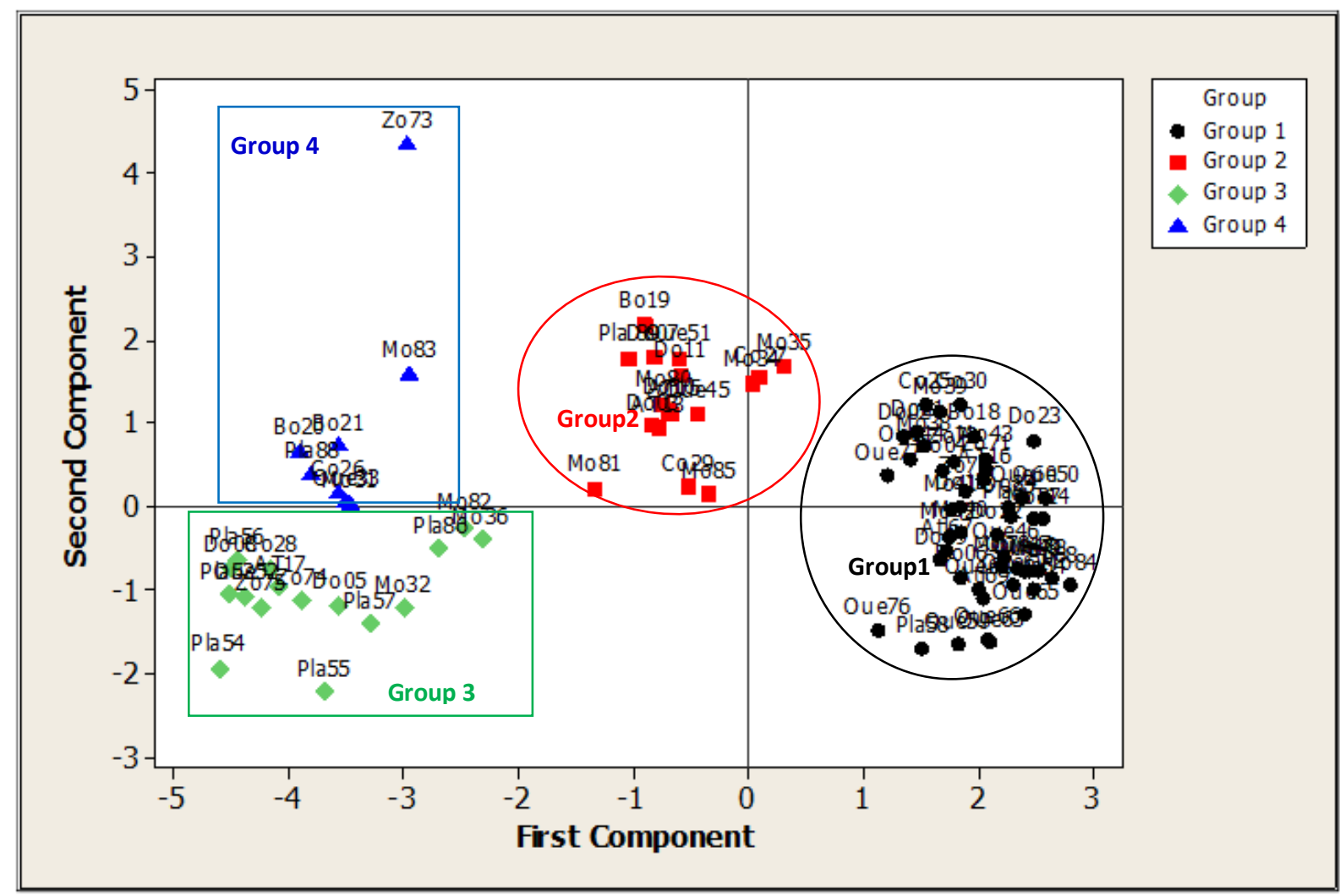

Fig. 3: Grouping of the accessions with principal component analysis using quantitative data.

The performances of each group are presented on Table 7. Accessions of group 1 are characterized by moderate leaf width, length leaf, length of stipule, large diameter of stem, high weight of stem and many internodes. Accessions of the group 2 are characterized by the high height of the stem, the large sized buds and the small number of nodes (small). They are highly productive (Table 7). Accessions of group 3 are characterized by long internodes and few nodes. The variability observed in this studied through PCA analysis is an important step in the genetic diversity study as it helps to select accessions to be considered in breeding programs (Sheela and Gopalan, 2006; Lahbib et al., 2012). For instance, crossing between accessions of group 1 and group 2 and between G1 and G3, would lead to respectively sugarcanes with height and big stems and with few nodes. According to Ekpélikpézé et al. (2016a), sugarcane with big stems and few nodes are easy to eat and have more economic value. Moreover the high productivity is one of the important criteria reported by 
sugarcane farmers. Regarding the characteristics of the different varieties in each group, local accessions need to be improved through crosses to generate high-yielding hybrids that can be promoted as observed on potato sweet (Norman et al., 2014), sorghum (Dossou-Aminon et al., 2015) and cassava (Agre et al., 2015).

Table 7: Variability of quantitative data through the different classes.

\begin{tabular}{|c|c|c|c|c|c|c|c|c|c|c|c|c|}
\hline Parameters & & $\mathbf{L L}$ & $\overline{\mathbf{L W}}$ & $\mathbf{L S}$ & SD & IL & SW & SN & BS & NI & DIN & PS \\
\hline $\begin{array}{l}\text { Class } 1 \\
(48\end{array}$ & Mean & 8.41* & $1.69 *$ & $6.47 *$ & $4.58 *$ & 10.72 & $5.04 *$ & 3.21 & 0.70 & $9.63 *$ & $4.90 *$ & 5.48 \\
\hline accessions) & Ecart type & 0.49 & 0.03 & 0.61 & 0.47 & 0.68 & 0.34 & 0.44 & 0.11 & 0.51 & 0.39 & 0.48 \\
\hline $\begin{array}{l}\text { Class } 2 \\
(17\end{array}$ & Mean & 6.45 & 1.58 & 5.68 & 3.91 & 12.06 & 3.76 & 3.25 & $0.85 *$ & 8.91 & 4.10 & 5.90 \\
\hline accessions) & Ecart type & 0.23 & 0.09 & 0.63 & 0.28 & 2.55 & 0.62 & 0.44 & 0.13 & 1.42 & 0.29 & 0.52 \\
\hline $\begin{array}{l}\text { Class } 3 \\
(19\end{array}$ & Mean & 5.52 & 1.45 & 4.46 & 3.02 & 14.80 & 2.79 & 3.12 & 0.63 & 7.22 & 3.18 & 4.91 \\
\hline accessions) & Ecart type & 0.66 & 0.08 & 0.59 & 0.41 & 2.09 & 0.69 & 0.52 & 0.21 & 1.00 & 0.37 & 0.72 \\
\hline & $\mathrm{CV} \%$ & 12.01 & 5.66 & 13.21 & 13.43 & 14.10 & 24.73 & 16.52 & 33.40 & 13.82 & 11.67 & 14.61 \\
\hline Class 4 & Mean & 5.72 & 1.45 & 4.53 & 2.97 & $16.04 *$ & 3.01 & $3.46^{*}$ & 0.80 & 6.66 & 3.25 & $6.04 *$ \\
\hline (5 accessions) & Ecart type & 0.23 & 0.01 & 0.10 & 0.04 & 1.03 & 0.20 & 0.22 & 0.18 & 0.50 & 0.13 & 0.16 \\
\hline
\end{tabular}

* Important value of the mean per line.

NB: LL: Length of the leaf; LW: Leaf width; LS: Length of the stipule; SD: Stem diameter; SW: Stem weight; SN: Sucker number; BS: Bud size; NI: Number of internodes; ND: Node diameter; PS: Plant size

\section{Conclusion}

The agromorphological characterization of eighty-nine (89) accessions of Saccharum officinarum showed that the sugarcane collection analyzed with qualitative and quantitative variables presented high variation. This genetic variability among accessions is an asset to the selection program. With the Principal component analysis, the accessions were grouped into four classes with complementary characters indicating opportunities for improvement and breeding. It is important to use in addition molecular and biochemical markers for better characterization of the accessions.

\section{Conflict of interest statement}

Authors declare that they have no conflict of interest.

\section{Acknowledgement}

We wish to thank the Laboratory of Biotechnology, Genetic Resources and Animal and Plant Breeding (BIORAVE) of the Faculty of Sciences and Technology of Dassa-Zoumé for financial support. We express our gratitude to Benin sugarcane producers particularly those of Djèrègbé and Sèmè-Podji districts for providing support, supplying samples and useful information during the documentation.

\section{References}

Abdelmahmoud, O. A., Ahmed, O., 2012. Correlation pattern among morphological and biochemical traits in relation to tillering capacity in sugarcane (Saccharum spp.). Acad. J. Plant Sci. 5(4), 119-122.

Adebo, H. O., Ahoton, L. E., Quenum, F., Ezin, V., 2015. Agromorphological characterization of Corchorus olitorius cultivars of Benin. Annu. Res. Rev. Biol. 7(4), 229-240.

Agre, A. P., Dansi, A., Rabbi, I. Y, Battachargee, R., Dansi, M., Melaku, G., Augusto, B., Sanni, A., Akoegninou, A., Akpagana, K., 2015. Agro morphological characterization of elite cassava (Manihot esculenta Crantz) cultivars collected in Benin. Int. J. Curr. Res. Biosci. Plant Biol. 2(2), 1-14.

Akoègninou,A., Van Der Burg, W. J., Van Der Maesen, L. J. G., 2006. Flore analytique du Bénin. Backuys Publishers, Cotonou \& Wageningen. 1034p.

Archimède, H., Xande, X., Gourdine, J. L., Fanchone, A., Alexandre, G., Boval, M., Coppry, O., Arquet, R., Fleury, J., Regnier, C., Renaudeau, D., 2011. La canne à sucre et ses co-produits dans l'alimentation animale. Innov. Agronomiq. 16, 165-179.

Bell, M. J., Halpin. N. V., Orange, D. N., Haines, M., 2001. Effect of compaction and trash blanketing on rainfall infiltration in sugarcane soils. Proceedings of the Australian Society of SugarCane Technologists. $23^{\text {rd }}$ Mackay, Queensland, 1-4 May 2001. pp.161-167.

Chavent, M., Kuentz, V., Saracco, J., 2007. Analyse en facteurs: présentation et comparaison des logiciels SAS, SPAD et SPSS. Rev. Modulad. 37, 1-30. 
Dossou-Aminon, I., Loko, Y. L., Adjatin, A., Ewédjè, B. K., Dansi, A., Rakshit, S., Cissé, N., Vishnu Patil, J., Agbangla, C., Sanni, A., Akoègninou, A., Akpagana, K., 2015. Genetic divergence in Northern Benin sorghum (Sorghum bicolor L. Moench) landraces as revealed by agromorphological traits and selection of candidate genotypes. Scient. World J. Article ID 916476, 10 pages. http://dx.doi.org/10.1155/2015/916476

Edmé, S. J, Miller, J. D., Glaz, B., Tai, P. Y. P., Comstock, J. C., 2005. Genetic contribution to yield gains in the Florida sugarcane industry across 33 years. Crop Sci. 45, 92-97.

Ekpélikpézé O., Loko L.Y, Dansi, A., 2016a. Diversité et évaluation participative des variétés de la canne à sucre (Saccharum officinarum) cultivées au Bénin. Int. J. Innov. Scient. Res. 2(2), 25-36.

Ekpélikpézé, O. S., Dansi, A., Agbangla, C., Akoegninou, A., Sanni, A., 2016b. Biochemical characterization of sugarcane varieties cultivated in Benin. Int. J. Curr. Microbiol. Appl. Sci. 5(2), 368-379.

Gbaguidi, A. A., Assogba, P., Dansi, M., Yedomonhan, H., Dansi, A., 2015. Caractérisation agromorphologique des variétés de niébé cultivées au Bénin. Int. J. Biol. Chem. Sci. 9(2), 1050-1066.

Gouy, M., 2012. Historique de l'amélioration de la canne à sucre et état de l'art des recherches en génétique d'association pour le rendement. Congrès sucrier ARTAS/ AFCAS 2012, La Réunion. 15p.

Grivet, L., Arruda, P., 2001. Sugarcane genomics: depicting the complex genome of an important tropical crop. Curr. Opin. Plant Biol. 5, 122-127.

IPGRI (International Plant Genetic Resources Institute), 1994. Annual Report-1993. Rome.

Jangpromma, N., Kitthaisong, S., Lomthaisong, K., Daduang, S., Jaisil, P., Thammasirirak, S., 2010. A proteomics analysis of drought stress-responsive proteins as biomarker for drought-tolerant sugarcane cultivars. Am. J. Agric. Biol. Sci. 6, 89-102.

Kawar, P. G., Devarumath, R. M., Nerkar, Y., 2009. Use of RAPD markers for assessment of genetic diversity in sugarcane cultivars. Ind. J. Biotechnol. 8, 67-71.

Kiebre, Z., Bationokando, P., Kiswendsida, R., Mahamadou, S. N., Zong, J-D., 2015. Caractérisation agromorphologique du caya blanc (Cleome gynandra L.) de l'Ouest du Burkina Faso. Int. J. Innov. Appl. Stud. 11(1), 156-166.

Lahbib, K., Bnejdi, F., Gazzah, M., 2012. Genetic diversity evaluation of pepper (Capsicum annuum L.) in Tunisia based on morphologic characters. Afr. J. Agric. Res. 7(3), 3413-3417.

Muhammad, S., Farooq, A. K., 2009. Genetic diversity among sugarcane cultivars in Pakistan. Am.-Euras. J. Agric. Environ. Sci. 6(6), 730-736.

Nair, N. V., 2009. Sugarcane Agriculture and Sugar IndustryCurrent Scenario and Future Prospect. International Training Course on Breeding Sugarcane for SugarIndustrial Complex, Sugarcane Breeding Institute, Coimabtore. pp.12-16.

Norman, P. E., Beah, A. A., Samba, J.A., Tucker, M. J., Benya, M. T., Fomba, S. N., 2014. Agrophenotypic characterization of sweet potato (Ipomoea batatas L.) genotypes using factor and cluster analyses. Agric. Sci. Res. J. 4(2), 30-38.

Pandey, A., Mishra, R. K., Mishra, S., Singh, Y. P., Pathak, S., 2011. Assessment of genetic diversity among sugarcane cultivars (Saccharum officinarum L.) using simple sequence repeats markers. J. Biol. Sci. 11(4), 105-111.

Pinto, L., Leite, D., Favero, T., Pastina, M., Garcia, A., Perecin, D., GonÃßalves, B., Creste, S., Xavier, M., Bidaia, M., 2011. Identification of microsatellites markers associated with yield components and quality parameters in sugarcane. Int. Sugar J. 113, 140-144.

Sheela, M. S., Gopalan, A., 2006. Association studies for yield and its related traits of fodder cowpea in F4 generation. J. Appl. Sci. Res. 2(9), 584-586.

Silva, C. M., Gonçalves-Vidigal, M. C., Filho, P. S. V., Scapim, C. A., Daros, E., Silvério, L., 2005. Genetic diversity among sugarcane clones (Saccharum spp.) Acta Sci. Agron. Maringá, 27, 2315-2319.

Singh, A., Pant, D., Korres, N. E., Nizami, A. S., Prasad, S., Murphy, J. D., 2010. Key issues in life cycle assessment of ethanol production from lignocellulosic biomass: challenges and perspectives. Bioresour. Technol. 101(13), 5003-5012.

Small, E., Catling, P. M., 2006. Blossoming treasures of biodiversity: 21. Sugarcane: an old star with a new act. Biodiver. 7(3-4), 37-46.

Sy, O., Amadou, F., Cissé, N., Noba, K. D., Diouf, D., Ndoye, I., Sane, D., Kane, A., Kane, N. A., Hash, T., Haussman, B., Elwegan, E., 2015. Étude de la variabilité agromorphologique de la collection nationale de mils locaux du Sénégal. J. Appl. Biosci. 87, 8030-8046.

\section{How to cite this article:}

Ekpélikpézé, O. S., Agre, P., Dossou Aminon, I., Adjatin, A., Dassou, A., Dansi, A., 2016. Characterization of sugarcane (Saccharum officinarum L.) cultivars of Republic of Benin. Int. J. Curr. Res. Biosci. Plant Biol. 3(5), 147-156. doi: http://dx.doi.org/10.20546/ijcrbp.2016.305.023 